has already received the patronage of the universities and leading scientific societies both at home and abroad, which will be represented by delegates. The programme of papers already contains contributions from the best known authorities on the history and ethnology of the vast region over which its operations extend. It may be hoped that the many persons interested in prehistoric America will assist in the work of the Congress, and that collectors will contribute specimens of antiquities to the exhibition which will be organised in connection with it.

In view of the approaching Congress, $\mathrm{Mr}$. Harlan J. Smith, superintendent of the Archæological and Ethnological branch of the Geological Survey of Canada, appeals for the aid of trained field-workers in the exploration of the vast number of prehistoric sites in various parts of the Dominion. In one township in Ontario a casual investigation disclosed no fewer than thirty ancient sites, and on the seacoast the kitchen middens are of great extent and interest. Canada at present cannot supply a sufficient staff of trained workers to carry on this survey, and the scheme suggests a promise of interesting scientific work in which some of the younger anthropologists trained in our university schools may be inclined to cooperate.

\section{PROF. EDWARD DIVERS, F.R.S.}

$W^{E}$ regret having to record the death of Prof. Edward Divers, F.R.S., which occurred on April 8. Born in London on November 27, r837, he was educated at the City of London School, at the Royal College of Chemistry, and at Queen's College, Galway. In I870 he was appointed lecturer on medical jurisprudence at the Middlesex Hospital Medical School, and in 1873 he went to Japan as professor of chemistry in the College of Engineering of the Imperial University at Tokyo, of which he became principal in 1882 . He remained in Japan until 1899 , when he was made emeritus professor and received the Order of the Sacred Treasure, in addition to that of the Rising Sun, which had been previously conferred upon him.

During the whole period of his active professorship, Dr. Divers alone and in collaboration with a succession of his Japanese students, Shimosé, Shimidzu, Haga, Kawakita, Nakamura, Ogawa, and Hada, was a prolific contributor to chemical science-hyponitrites, the constitution of fulminates, the quantitative separation of tellurium and selenium, the production of hydrosulphides, the constitution of sulphazotised salts, the red sulphur of Japan, hydrocarbon from Japanese petroleum, the composition of Japanese birdlime, the economical preparation of hydroxylamine sulphate, and many other subjects were dealt with in papers published in the Journal of the Chemical Society and the Philosophical Transactions. In 1893 he was elected a Fellow of the Royal Society.

On his return to England, Professor Divers did not cease his activity. He was a Vice-President of the Chemical Society and of the Institute of NO. 22 I6, VOL. 89]
Chemistry, President of the Chemical section of the British Association, President of the Society of Chemical Industry, and at the time of his death was still serving as the representative of the last-named society on the governing body of the Imperial College of Science and Technology, whilst as late as last year he contributed to the Society of Chemical Industry a lengthy paper on "A modification of Raschig's theory of the LeadChamber process."

Prof. Divers married in 1865 Margaret Theresa Fitzgerald, daughter of D. G. Fitzgerald, of Mayfield, Co. Cork, by whom he had one son and two daughters. His son died in early life, and he lost his wife in 1897 , shortly before his return from Japan, but his two daughters survive him. A man of fine physique, and, until within the last few months, of splendid health, he appeared to suffer only from defective sight, largely the result of a laboratory explosion, which practically destroyed the sight of his right eye. This accident happened in 1885 , but he did not allow it seriously to interfere with his work, though it was painful to others to watch him read or write with the book or paper held within a few inches of his eyes. In public he always felt the disability of being unable to recognise acquaintances that were more than a few feet distant, and this naturally gave him an appearance of reserve. But in small gatherings and among intimate friends he was a delightful companion, genial and humorous, especially pleased to talk about Japan and the Japanese, for everything connected with which he was always most enthusiastically appreciative, ever ready to discuss a chemical problem, and, to the last, keenly interested in chemical progress.

Prof. Divers leaves behind him in England and Japan a host of friends who will long mourn the loss of a very sterling character. He was buried at Brookwood on Thursday last, April ir, and though, in consequence of the Easter holidays, many of his friends were away from home, the Royal Society, the Chemical Society, the Society of Chemical Industry, the Institute of Chemical Industry, and the Institute of Brewing were all represented at his funeral and the memorial service. In addition to the members of his family, the following were present, viz. :-Sir Wm. Tilden, Prof. Emerson Reynolds, Prof. Gowland, Prof. Mondy, Prof. Hodgkinson, Dr. Rudolph Messel, Messrs. Tyrer, Reid, Hemingway, Grant Hooper, Coste, Baker, Cresswell, Pilcher, Carr, and others.

\section{NOTES.}

THE appalling disaster to the Titanic on Monday morning, by which more than 1300 of the passengers and crew have lost their lives, has brought several scientific subjects into prominence. Such subjects are: the dynamic effects of a mass of 50,000 tons moving at a speed of about is knots, the conditions of stability of a vessel built upon the watertight bulkhead system when an extensive injury has been 